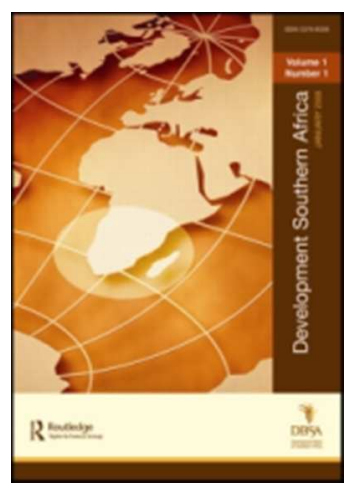

\title{
School attendance and economic shocks: Evidence from rural Zimbabwe
}

\begin{tabular}{|r|l|}
\hline Journal: & Development Southern Africa \\
\hline Manuscript ID & CDSA-2016-0225.R1 \\
\hline Manuscript Type: & Full length article \\
\hline Keywords: & children, education, Africa, economic shock \\
\hline JEL Codes: & J13, I21, N37, E31 \\
\hline \multicolumn{2}{|l}{} \\
\hline
\end{tabular}

SCHOLARONE $^{m}$

Manuscripts 


\title{
School attendance and economic shocks: Evidence from rural Zimbabwe
}

\begin{abstract}
:
Unpredicted shocks such as weather, pests or price changes affect agricultural households negatively or positively. The shocks have two opposite effects (Income and substitution) on parent's investments in human capital of their children, and it is not predictable from theory whether the income effect or the substitution effect of a shock has a greater impact on the investments. Therefore, it is unknown whether human capital investments (i.e. sending children to school rather than having them work) are procyclical or countercyclical. In this paper we show how hyperinflation may affect investments on the education of children by their parents using three data sets from Zimbabwe. We find that human capital investments are countercyclical (the substitution effect dominates) in rural areas of Zimbabwe during the shock. Therefore, policy makers in Zimbabwe need be worried about decreased schooling of children during positive shocks in the rural areas.
\end{abstract}

Keywords: children; education; Africa; economic shock.

JEL Codes: J13, I21, N37, E31. 


\section{Introduction}

Many children are sent to work instead of school in developing countries. In 2010, subSaharan Africa (SSA) had the highest rates of working children, with $26.2 \%$ of children aged 514 being employed in 2012 (Diallo, et al., 2013). SSA is one of the poorest regions of the world, and it also has one of the youngest populations (Bongaarts \& Casterline, 2013). These facts raise concerns about the employment and education of children. Sending children to work instead of school implies less human capital attainment and long-term reduction in economic growth, as the human capital stock is an important determinant of national economic growth (Jacoby \& Skoufias, 1997; Barro, 1991). Decisions about whether to send children to school or to work are affected by factors such as poverty, lack of resources, credit constraints, school quality, parental attitudes toward education, and imperfect credit and labour markets (Dumas, 2015; Basu \& Van, 1998; Ersado, 2005; Weir, 2011; see also Edmonds, 2007 for a literature review about child labour).

Zimbabwe is one of SSA countries where achievements in schooling are particularly noteworthy (Larochelle, et al., 2014). Achievements in education and other social services since Independence, however, are threatened by ongoing economic crises. The people of Zimbabwe have faced severe economic difficulties in the recent past. The country experienced a severe hyperinflation in 2007 and 2008 (Hanke \& Kwok, 2009). Hyperinflation can be considered as a negative shock $^{1}$ that affects schooling of children. In this paper, we study the role of shocks on decisions about sending children to school.

\footnotetext{
${ }^{1}$ In most less developed countries, the main source of income for rural households stems from agriculture. The majority of rural children are involved in agriculture, frequently being employed on their parents' farms (Edmonds \& Pavcnik 2005). Agriculture is susceptible to high uncertainty. Agricultural households are exposed to negative/positive shocks such as drought and heat stress, good rain falls, price variability, and 
It is theoretically indeterminate whether investments in children increase or decrease during negative/positive shocks. Suppose there is an adverse shock that reduces the price of agricultural products. The shock affects the decision to send the children to school via substitution and income effects. The direction of impact on this decision depends on which effect dominates. From one side, the shock decreases the income of the rural households, so children are pulled out of school and sent probably to work (Income effect). In this case we would observe procyclical human capital investments. From the other side, as a result of the price fall, the opportunity cost of time of children and adults fall, so incentive for putting children to work falls and the probability of sending children to school rises, and parents may even have more free time to take care of their children (Substitution effect). In this case we would observe countercyclical human capital investments. Thus theory cannot predict the direction of the effect of the shock on the amount of school attendance. By the same logic, it can be explained that the direction of the investments in the education of children cannot be predicted theoretically during positive shocks as well. Therefore, how school attendance changes after a negative/positive shock is an empirical question.

In our regressions, harvest time is the main independent variable, used to identify the effects of the shock on the education decision. When prices increase sharply every week (see Hanke \& Kwok, 2009), all prices change in an unpredictable fashion, and it is not clear which product prices increase more rapidly and which ones less. Farmers are unaware of prices after harvest, and they do not know whether the real price of their product will be higher or lower than past times. It is generally the case that the price of agricultural risk sharing strategies and mechanisms may exist, but such mechanisms tend to be inadequate in the face of widespread covariate shocks. Absence of coping tools contributes to a large variance of income and consumption and households may respond to shocks by removing their children from school. 
products falls after harvest due to rise of supply, but when there is hyperinflation, it is not predictable how much the prices will fall nor how they will change relative to other prices. Farmers observe the price of their products only after harvest, and when they go to market they become aware of the degree to which the hyperinflation affects them. By studying behavior before and after harvest time across different years, evidence is obtained on how decision making occurs. We do not claim that they have no sense about the prices before harvest. The process of gaining information about the price is gradual and sequential, but they will know the real prices after harvest with much more certainty.

It will be shown that educational investments are countercyclical in Zimbabwe. That is, opposite of expectation, substitution effect dominates and policy makers wishing to reduce child labour should be more concerned during positive shocks. Furthermore, we run two separate regressions for wealthy and poor households to explore the differences in the mechanism of the decision making of poor and wealthy households. We find that the substitution effect dominates for both groups during the crisis.

Understanding the mechanism driving household decision making about schooling and child labour during positive/negative shocks has important implications for policy makers wishing to reduce child labour or increase human capital. If the income effect dominates, safety net programs should be a priority during negative shocks, and if substitution effect dominates, then children are pulled out of school during positive shocks, so policy makers need be more cautious about child labour and schooling during positive shocks. Policy can lower costs of education and increase incentives for putting children in school during positive shock by providing voucher programs and subsidies to the school. For example, if a very good rain fall is forecasted in one 
part of a country, then we might expect a decrease of schooling (increase of child labour use), and policy makers should focus on areas where the positive shock is most prominent.

Many researchers have already studied the effects of shocks on the education/work of children. Many of these studies have been conducted using data from low income African, Asian and Latin American countries. Some studies show that investments on education are procyclical. For example, Hyder et al. (2015) show that negative economic shocks reduce the school enrolment of children in the rural areas of Malawi. Cogneau \& Jedwab (2012) studies the impact of a fall in producer price of an export crop (cocoa) on investments in children in Co^te d'Ivoire, and they find that human capital investments are procyclical. Edmonds \& Pavcnik (2005) show that Rice price increases are associated with declines in child labour in Vietnam. Beegle et al. (2008) show that crop shocks (pests or fire) or rainfall shocks lead to an increase in child labour in Tanzania (for more examples see Thomas et al. (2004) for Indonesia; Duryea et al. (2007) for Brazil; Jensen (2000) for Co^te d'Ivoire). Some studies show that investments on education are countercyclical. For example, schady (2004) studies the effects of a deep macroeconomic shock (30\% decrease in GDP) in Peru on school attendance and employment of children. They showed that children exposed to crisis were less likely to work and completed more grades than children unexposed to the crisis. In addition, some papers show that the decision making mechanism can be different for different groups of a society. For, example Kruger (2007) shows that during positive shocks in Brazil, education of poor children may be affected negatively, but education of rich children may not. Thomas et al. (2004) find similar results for Indonesia. Dumas (2015) shows that child labour increases when there is a positive shock in rainfall in Tanzania, but the amount of increase is less for the households who have access to labor markets. 
SSA countries appear to be different from other low income countries, because children in SSA suffer from deprivation, malnutrition and mortality severely more than other low income countries. In this paper, we study Zimbabwe. Munro (2015) shows that Zimbabwean children were affected very badly during the long crisis from circa 1990 to 2008 from many aspects (malnutrition/mortality/maternal mortality/health). Children might be in very dangerous situation during negative shocks due to the malnutrition and other problems, and consequently, they work more during the negative shocks for surviving. That is, it is expected that income effect dominates in SSA.

Our data set comes from three nationally representative household surveys conducted by Zimbabwe's National Statistical Agency (ZIMSTAT) in urban and rural areas of Zimbabwe in 2001, 2007/8 and 2011/12. These surveys contain information on household demographics, schooling, healthcare, employment and household enterprises, asset ownership, consumption expenditures and income.

The remainder of the paper is organized as follows: empirical specification is presented in section 2. The results from the empirical estimations are found in Section 3, and we conclude in Section 4.

\section{Empirical specification}

\section{1 data}

Three nationally representative household surveys conducted by ZIMSTAT are employed for the analysis. The Incomes, Consumption and Expenditure Surveys (ICES) were conducted 


\subsection{Variables}

Our dependent variable is defined based on two different questions in the questionnaire. There is a question in the questionnaire which asks: Has (name) ever attended school? and its answers are: 1) never been; 2) at school; and 3) left school. If a child has left school, then there is another question which asks about its reason. If a child aged 7-14 has never gone to school or has left school and this leaving is not because of illness then he/she is considered to be a child who is dropped out of school (There are not many children who have left school due to illness. There are only 49 children aged 7-14 across all three surveys). Therefore, our dependent variable is a

\footnotetext{
${ }^{2}$ Consider that the 2007/8 ICES survey was not conducted from January of 2008, and also the data collection of the 2001 ICES survey began in January, while the data collection of other years was started from June. Because time order is important in our analysis, we have to drop the observations which are collected from January to May in 2001 and 2011 in order to be able to compare the behavior of the farmers after harvest across different years during the same period of time.
} 
dummy variable, which is equal to one if a child is dropped out of school. In addition, recall from the introduction that our main independent variable is Harvest time ${ }^{3}$.

Consider that the structure of the survey is approximately balanced between two times of harvest and after that. We have approximately equal number of observations each month, and the mean values of main demographic and location variables approximately do not vary before and after harvest.

Before analyzing the income/substitution effects of the shock, we need to see whether the households experienced a negative shock or a positive shock in 2007. It is generally expected that hyperinflation is considered as an adverse shock. In rural areas of Zimbabwe most households state that their main source of income comes from sale of own agricultural products or their main activity has been farming during the past twelve months $(78 \%, 89 \%$ and $85 \%$ respectively in 2001, 2007 and 2011). Therefore, we treat all rural households as farmhouseholds. We can split farmers into two groups of net sellers and net buyers of agricultural products. Hyperinflation affects negatively net buyers, so the shock is a negative shock for them. If agricultural product prices are rising more rapidly than non-agricultural prices, then the net sellers of agricultural products experience a positive shock.

In order to establish whether net sellers were affected negatively during the hyperinflationary period, we calculate inflation for main crops of Zimbabwe between years 2006

\footnotetext{
${ }^{3}$ Harvest time in Zimbabwe depends on the pattern of movement of weather and type of agricultural products. weather travels from west to east, so harvest time of similar products is sooner in west, and some of the agricultural products are harvested sooner than others. Furthermore, some products are harvested only in west and some only in east because of differences in agro ecological characteristics. Because of these complications we cannot determine a specific month as harvest time in Zimbabwe, but most of main products are harvested from May to June. Remember that we have dropped months January-May, therefore only June is considered as harvest time. But, we consider July as harvest time as well. Because, first, due to weather changes harvest can be postponed in one year, second, it takes some time until farmers sell their products and realize their real income, so it takes some time until they make their decision about children. That is, we cannot see their behavior immediately at the end of June, therefore July is considered as harvest time as well.
} 
and 2007 using a producer price index (PPI), and compare these estimates to estimated inflation for consumption expenditures using CPI for the same years. We will see that the CPI increased much more sharply than the PPI, signaling that net sellers got poorer as relative prices changed.

It was explained that the shock affected farmers negatively. This shock can be considered as a large decrease in the relative price of agricultural products. After harvest, farmers see that their income falls. This income effect should be expected to lead to a rise in child work (less investment in the education of children). At the same time opportunity cost of time of children falls (demand for child labour falls) due to the decrease in the relative price of agricultural output. This substitution effect causes a decrease in child work (more investment in the education of children). In order to see which effect dominates, we regress the dependent variable (dropped out of school) on a dummy for harvest time and a complete set of covariates in each year. We find convincing evidence of an increase on the probability of being dropped out of school following harvest in 2001 and 2011, but a decrease after harvest in 2007 during the economic crisis. Results show that the substitution effect dominates the income effect in Zimbabwe.

Independent variables are listed in Table 1 with their definitions and summary statistics. It is necessary to explain a little bit about asset index. An asset index is calculated for each household using multiple correspondence analysis based on common assets owned by households. The assets are chosen such that they can be sold/bought easily in short run, because we want to see whether the households sell or buy their assets before and after harvest. The assets that we use are: plough, wheelbarrow, scotch cart, tractor, grinding mill, videotape/DVD, juice extractor, toaster, food mixer, washing machine, electric heater, stove, motor vehicle, fridge freezer, bicycle, television, radio, telephone, sewing machine. 


\section{Empirical Analysis}

\subsection{Was the hyperinflation a negative shock or a positive shock?}

In this section, we will show that all rural households are affected negatively in 2007.In section 2, it was explained that all rural households are split into two groups of net sellers (producers) of agricultural products and net buyers of agricultural products. Hyperinflation affects the net consumers negatively, so the shock is a negative shock for them. But, if agricultural prices were rising more rapidly than non-agricultural prices, then it might be thought that the net producers of agricultural products got richer and the shock was a positive shock for them.

We know that all prices including those of agricultural products were increasing quickly every week in 2007 (Hanke \& Kwok, 2009). The easiest way to find whether net sellers are affected negatively or positively in 2007 is to compute a monthly relative price index for agricultural products. But, only a few households in the 2007 reported how much agricultural products they have sold or consumed, while most of rural households in Zimbabwe are farmers, and the selling price that they report is noisy. Therefore, we need to find another way.

We fortunately could find some annual data for CPI and PPI in the website of food and agriculture organization of the United Nations ${ }^{4}$ (FAO) in 2000, 2001, 2006 and 2007, but there was no data for 2010 and 2011. In Table 2, we have reported annual inflation for main agricultural products of Zimbabwe (most of Zimbabweans produce maize) calculated using PPI

\footnotetext{
${ }^{4} \mathrm{http}: / /$ www.fao.org
} 
and also inflation for consumption expenditures calculated using CPI from 2000 to 2001, and from 2006 to 2007. All numbers are the percentage of the change of the price indices.

As it can be seen in Table 2, CPI increased far more than PPI in 2007 (the PPI of maize increased by $192 \%$, while CPI increased by $6827 \%$ ). That is, the relative price of farm output decreased dramatically and farmers were disadvantaged in other words, farmers experienced a substantial adverse shock in $2007^{5}$. But, the relative price of farm output compared to other goods increased in 2001 (the PPI of maize increased by 160\%, while CPI increased by 72\%); farmers received favorable prices in 2001 . This fact that the relative price increased substantially in 2001 is very helpful since it makes us enable to compare the behavior of the rural households in two opposite situations. We can even consider the price changes of year 2001 as a positive shock.

The direction of the shock can be examined in a different perspective by looking at household asset holdings. A comparison of the value of asset holdings before and after harvest for the three periods will indicate if 2007 was an abnormal year. An asset index is calculated for each household in the sample using MCA. Then, the mean of the index is computed for two time periods of harvest time and after the harvest. If the mean is higher after the harvest, then it means that the farmers get richer after harvest. But if the mean is lower after the harvest, then it means that the farmers get poorer after harvest (they sell their assets).

We test statistically whether the asset index of the rural households increased or decreased after harvest in each year using t-tests on the means of the indices (results are available upon

\footnotetext{
${ }^{5}$ Prices might be measured poorly in 2007 due to the crisis, but we are not worried about the conclusion made about the relative price. Because: first, the difference between the inflations in CPI and PPI is very large, so even if there is any mismeasurement, it cannot fill out the huge gap between the inflations. Second, the process of price collection is the same for both PPI and CPI, so if CPI is biased in a direction, then PPI should be biased in the same direction.
} 
request). The results show that in normal conditions (2001 and 2011), farm households buy assets after harvest which is reasonable, because after harvest, they sell their agricultural products and by the earned money they can buy more assets, while during the crisis, they sold their assets. This finding is consistent with the changes in relative price found in Table 2. Therefore, we conclude that the shock affected rural households adversely in 2007 . Now we are able to interpret income and substitution effects. There is no doubt that the hyperinflation affected all rural households negatively. Therefore, the income effect should lead to an increase in child work (decrease in child schooling) and substitution effect should induce a decrease in child work (increase in child schooling).

One objection to the use of the asset index arises from the possibility that the before and after harvest samples are actually of different populations. It is possible that the data was collected in rich areas prior to harvest and after harvest in poor areas in 2007, while the process of data collection was opposite in 2001 and 2011. Such sampling patterns could be associated with the results, to check this possibility, we checked the balance of all covariates listed in the Table 1 by testing equality of their means between harvest time and after harvest (the results are available upon request). We found that all covariates are balanced except asset index, school fee and the number of Males less than 7. It is reasonable why asset index and school fee are not balanced. We know that prices were increasing every week, so it is clear that these variables cannot be balanced.

\subsection{Estimated equation}

It was explained that the dependent is a dummy variable equal to 1 if a child is dropped out of school and 0 otherwise. We use a logit model to regress the dependent on the characteristics of 


\footnotetext{
${ }^{6}$ We control the unobservable regional fixed effects at three different geographical levels of province, district and subdistrict. Consider that after district, the smallest unit of census areas is ward. There are a few households by ward in the sample who have a child aged 7-14. The relatively small sample size by ward causes our dependent variable not to vary within in many wards. Consequently, after running regressions, all of those households who are in the wards are omitted because of collinearity. Therefore we need to merge those wards such that our dependent variable varies in each ward. To this end, we have divided each district into 2 or 3 parts based on the closeness of wards to each other and these parts are called subdistrict in this paper.

${ }^{7}$ Consider this limitation that household is nested in subdistrict, subdistrict is nested in district, and district is nested in province. We clustered errors at higher levels as well, and got similar results, but we prefer to cluster at the level of household since agro-ecological conditions change considerably in different areas of the Zimbabwe.
} 
It is possible that during the price shock some unobservable variables change, and that these unobservable variables are the main factors that affect child schooling, not the price shock. The only thing that we can do to mitigate the problem caused by the potential unobservables is to control for unobservable regional fixed effects and school fee. School fee vary monthly in each subdistrict, so in this way we control for the changes of school fee between subdistricts and also within subdistricts over time. Since the prices are rising sharply in 2007, we need to deflate school fee. To deflate it, we have divided it by the mean of the total consumption expenditures in each subdistrict and month. Inclusion of these variables allows for the possibility of unobserved institutional changes during the crisis which change the pattern of the changes of child schooling.

Estimation results are reported in Table 3. In this Table we report only the coefficients of the time dummy. Under the first three columns, we see the estimated log of odds ratios and under the last three columns we see marginal effects (ME).

In all regressions of Table 3, we controlled for a constant term, age and gender of child, age, gender and education of head, the number of males and females below 7 years old in household, the number of males and females above 15 years old in household, asset index, distance to primary school and secondary school, a cubic polynomial of per capita land holding (Oryoie et al. 2017) and regional fixed effects. In order to make sure that our results are robust, we control for different unobserved regional fixed effects by changing the size of regions from province to subdistricts. As we move downward in the Table from model 1 to model 5, our regional controls become more geographically specific. In the first regression, there is no regional fixed effect. In the next ones we control for unobserved fixed effects at the level of province, district and subdistricts respectively, and finally in model 5 we include school fee, which changes monthly at the level of subdistricts. 
Respectively in 2001, 2007 and 2011, there are on average 192, 283, and 382 rural households in the sample who have a child aged 7-14 in each province, and there are on average 28, 39 and 52 households in each district, and finally there are on average 16, 23 and 31 households in each subdistrict ${ }^{8}$. Because there are only a few households in each subdistrict, by controlling for unobserved subdistrict fixed effects, we are minimizing biases caused by unobserved household fixed effects (the best we can do in the absence of panel data).

As we see in Table $3, \log$ of odds ratios and MEs of time dummy are significant and pretty stable in all years across all models. Let's consider only the results of the model 5 in which there are more covariates and the regional fixed effect is the smallest one, although both log of odds ratios and MEs are approximately identical across all models. The MEs show that the probability of dropping out of school increases after harvest by about $2 \%$ in 2001 and $1 \%$ in 2011, but it decreases by about $2 \%$ after harvest during the crisis. That is, although the probability of being out of school is higher during the shock in comparison to the normal condition ${ }^{9}$, the probability changes in an opposite direction after the harvest time. It increases after harvest in normal conditions, while it falls after harvest during the shock.

Therefore, we see a dramatic change in the behavior of rural households after harvest during the negative shock in comparison to normal condition. One the one hand, It was shown in section 3.1 that rural households got poorer after harvest during the shock in 2007, but they got richer after harvest in both 2001 and 2011. On the other hand, the results in Table 3 shows that the probability of dropping children out of school increases after harvest in normal conditions (2001 and 2011), while the probability falls after harvest

\footnotetext{
${ }^{8}$ remember that we dropped the households who were surveyed from January to May

${ }^{9}$ Table 1 shows that the probability is about $10 \%$ during the shock, and it is about $7 \%$ in normal condition.
} 
during the shock (2007). By putting these two facts beside each other, we see that when households get richer the probability of pulling children out of school increases and when they get poorer the probability decreases. That is, the substitution effect dominates income effect $^{10}$ in rural areas of Zimbabwe. Therefore, policy makers wishing to reduce child work (increase investments in education) need to be more careful during positive shocks.

Here, a concern may arise. One might think that timing of academic year and vacations may cause the decrease in child schooling in 2007. But, consider that if this is a case, it must show up in 2001 and 2011 as well. Therefore, we should not be concerned about timing of academic year.

It is pretty reasonable that the mechanism of decision making be different between poor and wealthy households. We can expect that the income that wealthy households earn after harvest does not affect them such that they change their mind about putting children in school or pulling them out of school. They are wealthy and temporary changes of income affect them less. But, the story is different for poor households. Income changes may affect them prominently. In order to see whether or not wealthy households behave differently from poor households after harvest during crisis, and also in order to check again for further robustness of results, we divide households into two categories of poor and wealthy. For the classification we use the mean of the asset index separately in each year.

Results are reported in Table 4. The first (second) row shows log of odds ratios (MEs). The first (last) three columns stand for poor (wealthy) households. As we can see, respectively in 2001, 2007 and 2011, the MEs for poor (wealthy) households are equal to $2.2 \%(1.1 \%),-2.6 \%$ ($2.3 \%$ ) and $2.1 \%(0.03 \%)$. The $\log$ of odds ratios and MEs on the time dummy are both

\footnotetext{
${ }^{10}$ Recall that the income effect of a negative shock leads to a decrease in child schooling, and the substitution effect induces an increase in child schooling.
} 
significant for poor households in all years, but for wealthy households, they are significant only in 2007 .

First, as we see again, for both groups, MEs on harvest time are positive after harvest in normal conditions, while they are negative during the shock. Therefore, we conclude that the substitution effect dominates the income effect for both groups during the shock. Second, from the insignificancy (significancy) of the coefficients for wealthy (poor) households in normal conditions, we conclude that the decisions of wealthy (poor) households about pulling children out of school is not affected (is affected) by temporary changes of income in normal conditions, in other words, the decisions of the wealthy (poor) households about pulling children out of school are more stable (instable) in normal conditions. But, during the shock, both behave similarly. The MEs show that surprisingly the probability of pulling children out of school after harvest decreases by the same amount for both groups (by about $2.5 \%$ ).

\section{4) Conclusion}

We saw that Zimbabweans experienced an adverse shock in 2007-08, which caused rural households to get poorer. Shocks have opposite effects (income effect and substitution effect) on investments in the education of children, and theoretically it is not predictable which effect dominates.

Using three cross sectional surveys conducted in 2001, 2007-8 and 2010-11, we ran three different regressions in each year and controlled for regional unobservables and some institutional effects, and we saw that the probability of pulling children out of school usually increases after harvest in normal conditions, while it decreased after harvest during the price 
shock, which means that substitution effect dominates (human capital investments are countercyclical) in rural Zimbabwe.

Therefore, policy makers wishing to increase investments in the education of children should be worried during positive shocks since substitution effect dominates in Zimbabwe. That is, during positive shocks, opportunity cost of time of children increases.

\section{References}

Barro, R J, 1991. Economic Growth in a Cross Section of Countries. The Quarterly Journal of Economics 106(2), 407-443.

Basu, K \& Van, PH, 1998. The economics of child labour. American economic review 412-427.

Beegle, K, Dehejia, R, Gatti, R \& Krutikova, S, 2008. The Consequences of Child Labour: Evidence from Longitudinal Data in Rural Tanzania. Policy Research Working Paper no. 4677, World Bank, Washington, DC.

Bongaarts, J \& Casterline, J, 2013. Fertility Transition: Is sub-Saharan Africa Different?. Population and development review 38(s1), 153-168.

Cogneau, D \& Jedwab, R, 2012. Commodity Price Shocks and Child Outcomes: The 1990 Cocoa Crisis in Côte d'Ivoire. Economic Development and Cultural Change, 60(3), 507-534.

Diallo, Y, Etienne, A \& Mehran, F, 2013. Global child labour trends 2008 to 2012. ILO. 
Dumas, C, 2015. Shocks and child labor: the role of markets. Faculté des sciences économiques et sociales.

Duryea, S, Lam, D \& Levison, D, 2007. Effects of economic shocks on children's employment and schooling in Brazil. Journal of development economics 84(1), 188214.

Edmonds, E, 2007. Child labour. Handbook of development economics, 4, 3607-3709.

Edmonds, E \& Pavcnik, N, 2005. Child Labour in the Global Economy. Journal of Economic Perspectives 19(1), 199-220.

Edmonds, E \& Pavcnik, N, 2005. The effect of trade liberalization on child labour. Journal of international Economics 65(2), 401-419.

Ersado, L, 2005. Child Labour and Schooling Decisions in Urban and Rural Areas: Comparative Evidence from Nepal, Peru, and Zimbabwe. World Development, 33(3), 455-480.

Hanke, H \& Kwok, AKF, 2009. On the measurement of Zimbabwe's hyperinflation. The Cato Journal 29 (2), 353-364.

Hyder, A, Behrman, JR \& Kohler, HP, 2015. Negative economic shocks and child schooling: Evidence from rural Malawi. Development Southern Africa 32(4), 458476.

Jacoby, HG \& Skoufias, E, 1997. Risk, Financial Markets, and Human Capital in a Developing Country. The Review of Economic Studies 64(3), 311-335. 
Jensen, R, 2000. Agricultural volatility and investments in children. The American Economic Review 90(2), 399-404.

Kruger, DI, 2007. Coffee Production Effects on Child Labour and Schooling in Rural Brazil. Journal of Development Economics 82(2), 448-463.

Larochelle, C, Alwang, J \& Taruvinga, N, 2014. Inter-temporal changes in well-being during conditions of hyperinflation: Evidence from Zimbabwe. Journal of African Economies 23(2), 225-256.

Munro, LT, 2015. Children in Zimbabwe after the long crisis: Situation analysis and policy issues. Development Southern Africa 32(4), 477-493.

Oryoie, AR, Alwang, J \& Tideman, N, 2017. Child labor and household land holding: Theory and empirical evidence from Zimbabwe. World Development 100, 45-58.

Schady, NR, 2004. Do macroeconomic crises always slow human capital accumulation?. The World Bank Economic Review 18(2), 131-154.

Thomas, D, Beegle, K, Frankenberg, E, Sikoki, B, Strauss, J \& Teruel, G, 2004. Education in a Crisis. Journal of Development Economics 74(1), 53-85.

Weir, S, 2011. Parental Attitudes and Demand for Schooling in Ethiopia. Journal of African Economies 20(1), 90-110. 
Table 1. Definition of variables and descriptive statistics

\begin{tabular}{|c|c|c|c|c|}
\hline Variable & $\begin{array}{l}\text { Mean } \\
(\mathrm{sd})\end{array}$ & & & Definition \\
\hline & 2001 & 2007 & 2011 & \\
\hline $\begin{array}{l}\text { Dependent } \\
\text { Variable }\end{array}$ & $\begin{array}{l}0.07 \\
(0.26)\end{array}$ & $\begin{array}{l}0.10 \\
(0.29)\end{array}$ & $\begin{array}{l}0.06 \\
(0.23)\end{array}$ & $\begin{array}{l}\text { A dummy variable equal to } 1 \text { if a child aged } 7-14 \text { is not in school while } \\
\text { his/her not-attendance is not due to illness, and zero otherwise. }\end{array}$ \\
\hline Age & $\begin{array}{l}22.30 \\
(19.06)\end{array}$ & $\begin{array}{l}22.85 \\
(19.47)\end{array}$ & $\begin{array}{l}22.69 \\
(19.90)\end{array}$ & Age of child. \\
\hline Male & $\begin{array}{l}0.48 \\
(0.50)\end{array}$ & $\begin{array}{l}0.48 \\
(0.50)\end{array}$ & $\begin{array}{l}0.48 \\
(0.50)\end{array}$ & a dummy variable equal to 1 if a child is male, and 0 otherwise. \\
\hline Head education & $\begin{array}{l}0.26 \\
(0.44)\end{array}$ & $\begin{array}{l}0.34 \\
(0.47)\end{array}$ & $\begin{array}{l}0.45 \\
(0.50)\end{array}$ & $\begin{array}{l}\text { A dummy variable equal to } 1 \text { if head has at least a primary certificate and } \\
\text { zero otherwise. }\end{array}$ \\
\hline Head gender & $\begin{array}{l}0.64 \\
(0.48)\end{array}$ & $\begin{array}{l}0.65 \\
(0.48)\end{array}$ & $\begin{array}{l}0.65 \\
(0.48)\end{array}$ & Equal to 1 if head is male and 0 otherwise. \\
\hline Head age & $\begin{array}{l}46.92 \\
(15.28)\end{array}$ & $\begin{array}{l}47.76 \\
(16.35)\end{array}$ & $\begin{array}{l}47.86 \\
(16.36)\end{array}$ & Age of head of household. \\
\hline Males less than 7 & $\begin{array}{l}0.64 \\
(0.81)\end{array}$ & $\begin{array}{l}0.61 \\
(0.80)\end{array}$ & $\begin{array}{l}0.64 \\
(0.79)\end{array}$ & Number of males in household 6 years old and younger. \\
\hline Females less than 7 & $\begin{array}{l}0.64 \\
(0.80)\end{array}$ & $\begin{array}{l}0.60 \\
(0.77)\end{array}$ & $\begin{array}{l}0.63 \\
(0.78)\end{array}$ & Number of females in household 6 years old and younger. \\
\hline Males $15-50$ & $\begin{array}{l}1.15 \\
(0.98)\end{array}$ & $\begin{array}{l}1.22 \\
(1.03)\end{array}$ & $\begin{array}{l}1.14 \\
(0.95)\end{array}$ & Number of males in household between 15 and 50 years old. \\
\hline Females $15-50$ & $\begin{array}{l}1.39 \\
(0.94)\end{array}$ & $\begin{array}{l}1.40 \\
(0.95)\end{array}$ & $\begin{array}{l}1.27 \\
(0.86)\end{array}$ & Number of females in household between 15 and 50 years old. \\
\hline Land per L & $\begin{array}{l}0.73 \\
(14.29)\end{array}$ & $\begin{array}{l}0.65 \\
(5.40)\end{array}$ & $\begin{array}{l}0.56 \\
(0.63)\end{array}$ & $\begin{array}{l}\text { Amount of land holding in hectares divided by the number of individuals in } \\
\text { household greater than } 6 \text { years old. }\end{array}$ \\
\hline Asset & $\begin{array}{l}1.86 \\
(4.69)\end{array}$ & $\begin{array}{l}1.94 \\
(4.68)\end{array}$ & $\begin{array}{l}4.08 \\
(6.47)\end{array}$ & Asset index ${ }^{1}$ \\
\hline $\begin{array}{l}\text { School fee } \\
\text { primary school }\end{array}$ & $\begin{array}{l}0.02 \\
(0.04)\end{array}$ & $\begin{array}{l}0.03 \\
(0.03)\end{array}$ & $\begin{array}{l}0.04 \\
(0.04)\end{array}$ & $\begin{array}{l}\text { Mean of School fee } e^{2} \text { divided by total consumption expenditures in each } \\
\text { ward and each month. } \\
\text { Distance to Primary school in } \mathrm{Km} \text {. }\end{array}$ \\
\hline Secondary school & & & & Distance to Primary school in $\mathrm{Km}$. \\
\hline
\end{tabular}

1. Asset index is scaled such that it varies from 0 to 100 .

2. Pre-school fees, School tuition fees (excluded payments for food, beverage \& shelter), Parents and Teachers' association fee or levy or building fund, uniform, School shoes, School sports wear, Exercise books, Ball pens, pencils, erasers and other stationery for school, Educational books, School bus or transport cost, Boarding fees, Other tuition and correspondence fees, Other expenses on education 
Table 2. Annual inflation rates $(\%)$

Agricultural products

\begin{tabular}{|c|c|c|c|}
\hline \multicolumn{2}{|c|}{$2000-2001$} & \multicolumn{2}{|c|}{ 2006-2007 } \\
\hline PPI & CPI & PPI & CPI \\
\hline $160 \%$ & & $192 \%$ & \\
\hline $67 \%$ & $72 \%$ & $204 \%$ & $6827 \%$ \\
\hline $\begin{array}{l}133 \% \\
200 \%\end{array}$ & $12 \%$ & $\begin{array}{l}172 \% \\
232 \%\end{array}$ & $0821 \%$ \\
\hline
\end{tabular}

All numbers are in percentage. CPI is calculated based on consumption prices of all goods and services included agricultural goods. 
Table 3. Log of odd ratios and marginal effects of time dummy on the probability of not being in school, various model specifications.

\begin{tabular}{|c|c|c|c|c|c|c|}
\hline \multirow[t]{2}{*}{ Models } & \multicolumn{3}{|c|}{ Log(Odds) } & \multicolumn{3}{|c|}{ ME } \\
\hline & 2001 & 2007 & 2011 & 2001 & 2007 & 2011 \\
\hline No Fixed effect(1) & $\begin{array}{l}0.227^{*} \\
(1.87)\end{array}$ & $\begin{array}{l}-0.294 * * * \\
(-3.24)\end{array}$ & $\begin{array}{l}0.271 * * \\
(2.33)\end{array}$ & $\begin{array}{l}0.015^{* *} \\
(1.96)\end{array}$ & $\begin{array}{l}-0.025 * * * \\
(-3.12)\end{array}$ & $\begin{array}{l}0.012 * * \\
(2.41)\end{array}$ \\
\hline Province fixed effects(2) & $\begin{array}{l}0.254^{* *} \\
(2.08)\end{array}$ & $\begin{array}{l}-0.292^{* * *} \\
(-3.18)\end{array}$ & $\begin{array}{l}0.280 * * \\
(2.45)\end{array}$ & $\begin{array}{l}0.017^{* *} \\
(2.20)\end{array}$ & $\begin{array}{l}-0.025^{* * *} \\
(-3.07)\end{array}$ & $\begin{array}{l}0.012 * * \\
(2.53)\end{array}$ \\
\hline District fixed effects(3) & $\begin{array}{l}0.272 * * \\
(2.08)\end{array}$ & $\begin{array}{l}-0.290 * * * \\
(-3.18)\end{array}$ & $\begin{array}{l}0.247 * * \\
(2.20)\end{array}$ & $\begin{array}{l}0.017^{* *} \\
(2.20)\end{array}$ & $\begin{array}{l}-0.024 * * * \\
(-3.08)\end{array}$ & $\begin{array}{l}0.011^{* *} \\
(2.27)\end{array}$ \\
\hline Subdistrict fixed effects(4) & $\begin{array}{l}0.271 * * \\
(1.99)\end{array}$ & $\begin{array}{l}-0.273 * * * \\
(-2.93)\end{array}$ & $\begin{array}{l}0.215^{*} \\
(1.87)\end{array}$ & $\begin{array}{l}0.017^{* *} \\
(2.09)\end{array}$ & $\begin{array}{l}-0.023 * * * \\
(-2.85)\end{array}$ & $\begin{array}{l}0.009^{*} \\
(1.92)\end{array}$ \\
\hline $\begin{array}{l}\text { Subdistrict fixed effects } \\
\text { included school fee (5) }\end{array}$ & $\begin{array}{l}0.263^{*} \\
(1.93)\end{array}$ & $\begin{array}{l}-0.282 * * * \\
(-2.92)\end{array}$ & $\begin{array}{l}0.193 * \\
(1.68)\end{array}$ & $\begin{array}{l}0.017^{* *} \\
(2.02)\end{array}$ & $\begin{array}{l}-0.023 * * * \\
(-2.83)\end{array}$ & $\begin{array}{l}0.008^{*} \\
(1.72)\end{array}$ \\
\hline $\begin{array}{l}N \\
R^{2} \\
\end{array}$ & $\begin{array}{l}8581 \\
0.08\end{array}$ & $\begin{array}{l}12184 \\
0.1\end{array}$ & $\begin{array}{l}14675 \\
0.11\end{array}$ & 8581 & 12184 & 14675 \\
\hline
\end{tabular}

*Denotes significance at $10 \%, * *$ at $5 \%$ and $* * *$ at $1 \%$. Numbers in parentheses are t statistics. Standard errors are clustered at the household level. Marginal Effects are calculated at means. All regressions include a constant, age and gender of child, age, gender and education of head, the number of males and females below 7 years old in household, the number of males and females above 15 years old in household, asset index, distance to primary school and secondary school, a cubic polynomial of per capita land holding and regional fixed effects, but model 1 in not included regional fixed effects. The model 5 include mean of school fee over total consumption expenditures in each month and each subdistrict as well. 
Table 4. Log of odds ratios and marginal effects of time dummy on the probability of not being in school. Logit models for poor and wealthy households.

\begin{tabular}{|c|c|c|c|c|c|c|}
\hline \multirow[b]{3}{*}{ Log(odds) } & \multicolumn{3}{|c|}{ Poor Households } & \multicolumn{3}{|c|}{ Wealthy Households } \\
\hline & 2001 & 2007 & 2011 & 2001 & 2007 & 2011 \\
\hline & $\begin{array}{l}0.274^{*} \\
(1.85)\end{array}$ & $\begin{array}{l}-0.255^{*} \\
(-1.94)\end{array}$ & $\begin{array}{l}0.388^{* * * *} \\
(2.59)\end{array}$ & $\begin{array}{l}0.211 \\
(1.06)\end{array}$ & $\begin{array}{l}-0.329 * * \\
(-2.34)\end{array}$ & $\begin{array}{l}0.095 \\
(0.56)\end{array}$ \\
\hline ME & $\begin{array}{l}0.022 * \\
(1.93)\end{array}$ & $\begin{array}{l}-0.026^{*} \\
(-1.89)\end{array}$ & $\begin{array}{l}0.021 * * * \\
(2.71)\end{array}$ & $\begin{array}{l}0.011 \\
(1.11)\end{array}$ & $\begin{array}{l}-0.023 * * \\
(-2.24)\end{array}$ & $\begin{array}{l}0.003 \\
(0.57)\end{array}$ \\
\hline$N$ & 4104 & 5909 & 7350 & 4542 & 6275 & 7325 \\
\hline$R^{2}$ & 0.06 & 0.07 & 0.06 & 0.05 & 0.05 & 0.1 \\
\hline
\end{tabular}

*Denotes significance at $10 \%, * *$ at $5 \%$ and $* * *$ at $1 \%$. Numbers in parentheses are t statistics. Standard errors are clustered at the household level. All regressions include a constant, age and gender of child, age, gender and education of head, the number of males and females below 7 years old in household, the number of males and females above 15 years old in household, asset index, distance to primary school and secondary school, a cubic polynomial of per capita land holding and province fixed effects. 